\title{
The Spread of the Prison Subculture as a Driver of Its Destructive Influence on the Personality of Young Correctional Officers
}

\author{
VITALII E. LAPSHIN \\ Vladimir State University Named After Alexander and Nikolay Stoletovs, Vladimir, \\ Russian Federation, Vladimir Law Institute of FSIN Russia, Vladimir, Russian \\ Federation, Vologda Institute of Law and Economics of FSIN Russia, Vologda, \\ Russian Federation \\ ORCID: https://orcid.org/0000-0002-6243-9532, e-mail:ve_lapshin@mail.ru
}

\section{TAT'YANA V. GALICH}

Vladimir Law Institute of FSIN Russia, Vladimir, Russian Federation

ORCID: https://orcid.org/0000-0001-5111-4698, e-mail: t_galich@list.ru

\section{Abstract}

Introduction: we study the negative impact of the prison subculture on the personality of a correctional officer. Amid the social crisis caused by the collapse of the USSR the prison subculture started to penetrate into popular culture. This was reflected in the widespread use of prison slang, increased interest in the way of "thieves' life", and the popularization and romanticization of crime bosses. Behind all this was the devaluation of the norms of law and the state, and the distortion of the status of the penal system officer. Aim: on the basis of generalization of modern experience in studying the impact of the prison subculture, we describe main directions aimed at preventing the destructive impact of the prison subculture on the personality of young correctional staff. The article deals with the issue of modern dissemination of the prison subculture among young people via the mass media, the Internet and oral transmission of information. Methods: we use empirical data collection methods (questionnaires, conversations, interviews), and methods of statistical analysis and system analysis of the data collected. Results: the findings of our research show that the prison subculture infects not only disadvantaged teenagers, but also young people from a socially favorable environment, who then enter departmental universities and serve in correctional institutions. Infection is assessed by the degree of internal involvement of a young person in the prison subculture. In the lightest form of this infection, they simply are well informed about what it is, know the meaning of prison slang expressions, understand the logic of the functioning of groups of inmates, and are favorably disposed toward these phenomena. When the infection is more complex, future and young correctional officers not only demonstrate awareness and tolerance, but also consider the prison subculture necessary and useful; they do not condemn colleagues who use it in solving official tasks and are themselves ready, if necessary, to act in this way. Discussion: general awareness of the specifics of the prison subculture is necessary for the penal system officer, but it should remain a professional knowledge that helps to assess social relations in the group and the operational situation in the correctional institution adequately. At the same time, the prison subculture should receive an objective assessment as an anti-humanistic and anti-legal phenomenon. Therefore, there is a need for systematic and targeted work to prevent the spread and deforming effects of the prison subculture among cadets of departmental universities and young correctional officers.

Keywords: subculture; prison subculture; inmates; correctional institutions; cadets; correctional officers; prevention of professional deformation; correction of the personality of a penal officer.

19.00.06 - Legal psychology.

For citation: Lapshin V.E., Galich T.V. The spread of the prison subculture as a driver of its destructive influence on the personality of young correctional officers. Penitentiary Science, 2021, vol. 15, no. 2 (54), pp. 434-442. DOI 10.46741/2686-97642021-15-2-434-442. 


\section{Introduction}

The term "subculture" first appears in the Chicago School of Sociology in the context of research at the intersection of sociology and ethnography and refers to the life of ethnic communities and marginal groups [2].

Speaking about the prison subculture, we mean a set of spiritual and moral values that regulate the informal life of inmates in places of deprivation of liberty [6, p. 31]. That is, we mean not only a set of conventions, but a social regulator that determines the development specifics of socio-psychological phenomena in a correctional institution and forms the sociopsychological climate within the institution. A large number of inmates inevitably determine their own values and require community members to take into account the norms and traditions accepted in this environment [1].

The norms and values of the criminal and prison subculture themselves have a high degree of referentiality, they are powerful regulators of individual conduct, since they act through the mechanisms of mental infection, imitation and pressure [3].

According to researchers, the prison subculture is a self-organizing system, which is characterized by the emergence of new properties in existing groups of actors; this preserves it and allows it to adapt to new conditions [12]. At the same time, the prison subculture is currently gaining new distribution channels - the Internet and social media [11].

According to researchers, specific features of the prison subculture result from its own ways of formation and functioning [4]. The key factors are the closed environment of the institution, isolation, and the restriction of the possibility of choosing a circle of communication or an occupation. The content of the prison subculture includes not only norms of conduct and stratification, but also vocabulary, folklore, and aesthetics [16]. Young people find it especially attractive due to the fact that it possesses elements of a game [15]. In places of deprivation of liberty, inclusion in the prison subculture is forced, since it is one of the ways to adapt to the conditions of doing one's time.

A.N. Oleynik identifies the following criteria for studying the structure of the prison subculture: the degree of differentiation of the spheres of daily activity, the degree of personification of relations, the degree of dualism of social norms and the degree of institutionalization of violence [10]. That is, in a correctional institution, inmates have virtually no opportunity to lead a private life. They are always in plain sight, among other inmates and correctional staff. Therefore, gradually, even against their will, inmates became saturated with the prison subculture and start opposing themselves to the penal system, the state and the law.

Like any other subculture, the prison subculture reflects the values and moral norms of its main carriers - inmates. Therefore, under the "romance" that we see on the surface, there is a world that is focused on anti-legal and antihumanistic behavior. This type of behavior, elevated to an ideal, allows inmates to maintain respect for themselves, find their place in the criminal world and maintain their authority. In itself, the presence of a prison subculture in correctional institutions is a problem that reduces the effectiveness of educational influence and increases the level of prison crime, especially if the staff themselves fall under its influence.

At present, particularly dangerous is the exportation of the prison subculture outside the prison walls and its merging with mass culture. In the modern Russian and Western reality, elements of the prison subculture have become part of various spheres of life. Examples of the use of rituals, traditions, vocabulary and norms of conduct can be found in mass culture, politics, business, and everyday life [14; 17; 18; 19].

While preparing his novel One Day in the Life of Ivan Denisovich for publication, A.I. Solzhenitsyn supplemented the text with a special short dictionary of prison slang, because in 1962 it was familiar only to people associated with the penal system. And for quite a long time, the interest in the prison subculture was narrow, but already in the 1990s, amid the social crisis, the prison subculture began to penetrate into the general culture. On the one hand, this was facilitated by the criminalization of the population, on the other hand by the popularization and romanticization of the prison subculture in films and TV series (Brigada [Brigade], Banditskii Peterburg [Bandit Petersburg], Po prozvishchu Zver' [His Nickname Is Beast], etc.).

In the course of this merger, the prison vocabulary became common, and the norms and behaviors of the "thieves' law" became widespread among youth groups, which led to the formation of the AUE movement [AUE - "Arestantsky. Uklad. Edin," or "Prison. Order. Universal" is a criminal subculture and an informal hidden organization of Russian criminals, mainly consisting of children and teenagers. Translator's note] and the active use of prison subculture themes in the work of modern performers 
who are popular among young people. The main problem is the fact that all these manifestations are aimed at "whitewashing" criminals and justifying their inhumane and anti-legal actions, and the grounds for this were laid down in the 1990s.

The need to prevent the spread of the prison subculture among inmates (especially minors) is obvious and has long been in the focus of attention of penitentiary teachers and psychologists (M.G. Debolskii, V.F. Pirozhkov, V.M. Pozdnyakov, etc.). But it is only recently that the need for targeted and system-wide prevention of the negative impact of the prison subculture on the personality of a young person who is not associated with the penal system has come to the fore.

S.A. Luzgin points out that some elements of the prison subculture are actively introduced into the youth environment thus creating a dangerous negative trend, since this process causes destructive implications for the formation of the personality of a young individual [8].

Studies of convicted minors "infected" with the prison subculture reveal that the primary "infection" with the prison subculture occurs on the outside. And teenagers enter educational colonies with already established "thieves'" views and values [13].

But as practice shows, a similar trend has begun to emerge among applicants to departmental universities and young correctional officers. If in the past, "infection" with the prison subculture was one of the signs of professional deformation of a correctional institution officer and manifested itself after several years of work in the institution, then today the penal system employs young people who are already familiar with the prison subculture in absentia from films, songs, articles and videos of popular bloggers on the Internet. As noted above, the vast majority of this cultural material instills sympathy for criminal life and criminal values.

\section{Research methods}

In 2019-2020, we conducted a study aimed at determining the possibilities of correcting the involvement of cadets of Vladimir Law Institute of the Federal Penitentiary Service of Russia (VLI FSIN Russia) and young correctional officers in the prison subculture.

The aim of the study was to identify ways to correct the involvement of cadets and young correctional workers in the prison subculture. To achieve this goal, it was planned to address the following tasks:
1. To conduct a study of the level of involvement of cadets and young staff in the prison subculture.

2. Based on the results of the study, to develop a correctional program aimed at neutralizing the negative impact of subculture.

3 . To analyze the results of the program implementation.

The hypothesis of the study: the involvement of the cadets of the departmental university and young staff of correctional institutions in the prison subculture is superficial and spontaneous, and therefore can be adjusted through a system of psychological and pedagogical measures.

The study involved correctional staff with service experience from one to three years (30 people), who are studying at the correspondence department of the Law Faculty of VLI FSIN Russia and who are taking initial training courses at the Faculty of Professional Education and Additional Education of VLI FSIN Russia and cadets of the second year of full-time training at the Law Faculty of VLI FSIN Russia (30 people).

To determine the level of involvement in the prison subculture, the methods of questionnaires, surveys and expert assessments were used. Since we had the opportunity to observe the respondents in their academic and professional activities, we could assess their relationships with colleagues, their attitude toward discipline and official duties, and their level of general culture. The experts were lecturers from VLI FSIN Russia and staff of correctional institutions who hold senior positions or act as mentors.

When developing the questionnaire, we were guided by the theory of L. Kohlberg, according to which morality is a process consisting of cognitive, operational, and motivational levels [10].

The cognitive level includes the system of beliefs, knowledge, concepts, rules, assessments, norms, values, as well as the attitude toward these phenomena. The motivational level implies an internal permission to put into practice the elements of the prison subculture to meet one's needs. The operational level assumes that the use of elements of subculture is included in the practice of real activity.

A superficial level of involvement can be described if the respondent has general information about the prison subculture as a social phenomenon, has a professional interest in it, dictated by official duties, has a negative atti- 
tude toward it, does not consider themselves as part of the prison subculture, does not use elements of the prison subculture in their daily personal or official activities, and condemn such use by other penal officers.

The borderline level of involvement implies that the respondent is aware of the prison subculture, feels not only professional, but also personal interest in it, assumes a neutral attitude toward it, uses elements of the prison subculture in official and personal life (uses prison slang), can consider some norms of the prison subculture fair and justify their existence by necessity, approves of cases of use of elements of the prison subculture by correctional staff for official purposes.

A critical level of involvement can be described if the respondent has a deep knowledge of the prison subculture at the level of nuances, seeks to immerse themselves in the prison subculture and sees it as an opportunity for selfrealization, approves of its existence and considers it necessary for the quality functioning of the correctional institution, shares the values of the prison subculture, treats it positively, supports those officers who do not fight with the prison subculture, but use it to achieve official goals.

The questionnaire was aimed at identifying the level of awareness of respondents about the prison subculture (general information, specific nuances, features of the history of formation), their attitude toward various cases of manifestation of the prison subculture among inmates and staff (sympathize, justify, find it difficult to evaluate, evaluate negatively, etc.), and assessing the readiness to act in controversial official situations from the standpoint of prison subculture norms (it was suggested to choose an action option from the ready-made ones or to write their own version).

The experts were asked to assess the extent to which young people entering the service in correctional institutions are involved in the prison subculture, what difficulties this causes in their adaptation and professional development.

\section{Results of the study}

The results obtained allow us to draw the following conclusions:

1. Both groups of respondents (cadets and staff) are well acquainted with the history, elements and structure of the prison subculture. When asked to list the elements of the prison subculture, they named prison slang, gestures, tattoos, folklore, crafts, codes of laws, the hi- erarchy of convicts, rituals, and gave specific definitions of these phenomena; they could give relevant examples.

In a group of cadets, some of the information is outdated or exaggerated, because in the second year of training there was no internship in correctional institutions, and all the information came from open information sources. Young staff also noted that they came to work in the correctional institution already having knowledge about the prison subculture and its impact on relations within groups of inmates.

The following answers were received to the question about the sources of information about the prison subculture:

Mass media - 51\%;

Movies and TV series - 31\%;

Conversations with peers at school - 13\%;

Conversations in the family $-5 \%$.

Thus, we can see that the share of open information sources is quite large. The information provided in open sources is distorted, does not correspond to the time, is emotionally colored, and exploits the popular trend of creating a negative image of a law enforcement officer.

2. The respondents of both groups are well acquainted with the slang expressions typical of the prison subculture. They actively use such words as zapadlo [it's beneath my dignity], bespredel [lawlessness], otritsalovo [inmates who are ill-disposed toward prison administration and staff and who negatively influence other inmates], zagasit'sya [to hide oneself], zashkvar [dishonorable act], etc. The respondents themselves do not see anything reprehensible in the use of these words, perceive them as part of everyday life and do not believe that they clutter up their speech; nor do they associate themselves with the prison subculture. In addition to individual words, respondents indicated that they used such stable expressions as ego mesto $u$ parashi [his place is near the close-stool], poshli na strelku pereteret' vopros [went to the pre-arranged meeting to discuss an issue], kipeshnul i slil [made a row and killed smb.], etc.

3. In the block of questions that concerned the attitude toward the prison subculture, there were differences of opinion.

The staff who already have some experience working and interacting directly with criminalized individuals pointed to negative manifestations of the prison subculture. The average assessment of the manifestations of the prison subculture in this group is as follows:

The prison subculture deforms the personality, negatively affects people, deprives them 
of their self-esteem, pushes them to commit crimes, but it keeps order inside the institution and is difficult to fight.

Respondents from the second group (cadets), who are not personally acquainted with the carriers of the prison subculture, gave different assessments of this phenomenon, which does not allow us to make a single average statement. The attitude within this group was distributed as follows:

Find it difficult to express their attitude $-5 \%$;

Consider the prison subculture an important historical and cultural element of the penal system, romanticize it, and attach non-existent significance to it - $20 \%$;

See the negative side of the subculture in the open manifestation of violence and attempts on sexual integrity, but believe that the prison subculture should exist so as to maintain order 25\%;

Recognize the inhumane content of the prison subculture, but show an active interest in particular individuals (code-bound thieves) $30 \%$;

Show a neutral attitude toward the prison subculture, as to any other subculture $-50 \%$.

The respondents of the first group (correctional staff) are characterized by a less positive and romantic attitude toward the subculture. They note its negative nature and corrupting influence on people. This is due to the fact that members of this group are involved in faceto-face interaction with actual carriers of the prison subculture and have no illusions about selfless protection and assistance to the "weak and wrongfully convicted". But this group also expresses the opinion that it is difficult for correctional staff to resist the phenomena of subculture and that it can be useful for them.

4. Cadets' answers show the tendencies toward mythologizing and romanticizing the activities of "code-bound thieves". Respondents were asked to list the qualities inherent in criminal authorities and "code-bound thieves". The most commonly used characteristics were "bold", "strong", "smart", "able to manage people", "decisive". That is, we see positive characteristics that transfer crime bosses from the level of a criminal to the level of a hero.

They mentioned the following sources of knowledge about crime bosses: YouTube videos, a recording of an interview with Aleksandr Severov (NTV channel, Confessions of a CodeBound Thief, 2014), etc.

Among correctional staff, the characteristics were either neutral: "they are human too", "they are complicated", or negative: "they are thuggish", "cunning", "dangerous". But in the course of conversations, staff noted that before joining the service, they also had had illusions and believed false information.

5. The answers of the staff and cadets contained some common features, mainly an indication that the very environment of the correctional institution often equates the inmate and staff, since both are under pressure from the regime and conditions for the implementation of official activities. According to respondents, the administration of the correctional institution does not always show proper behavior toward the staff, especially toward young ones. Such an attitude reduces the officer's self-esteem, disorients them in official relations and leads to an awareness of common features in their own position and the position of inmates. This assessment results in a rapid assimilation of the prison subculture.

That is, we can see that the vast majority of respondents show cognitive infection; that is, at the cognitive level, the prison subculture is perceived not as part of the environment in which respondents perform their official duties, but as part of the general cultural world; this means the survey participants recognize its right to exist and are more ready to adapt to it than to eradicate it.

In addition, out of the total number of respondents, 34\% positively assessed cases in which an officer solved official tasks through the means of the prison subculture (negotiated with a crime boss, for example). And 15\% indicated that they themselves were ready to take into account manifestations of the prison subculture in their official activities, but if necessary, use them to address official tasks.

Thus, almost a third of respondents have a motivational infection.

Unfortunately, the lack of opportunities to carry out direct observation of the performance of the duties of surveyed respondents does not allow us to conclude that they have the operational infection, but in the presence of cognitive and motivational infections, the risk of manifestation of these trends in the operational sphere becomes quite high.

The results obtained do not allow us to speak about a critical level of involvement in the prison subculture. According to the results of the analysis of questionnaires and interviews, it was found that $45 \%$ of respondents are superficially involved in the prison subculture. Of these, $65 \%$ are cadets and $35 \%$ are correctional staff. The 
predominance of cadets can be explained by the fact that they have a higher level of general culture, more opportunities for self-development (participation in scientific and creative activities, constant personal development), as well as a wider circle of communication, which includes people who are not connected with the service in the penal system.

Thirty-five percent of the surveyed have a borderline level of involvement, close to the superficial level (that is, they show an increased interest in the prison subculture, may use some elements of the prison subculture in life, but do not approve of the use of the prison subculture in official situations). Of these, $88 \%$ are staff and $12 \%$ are cadets. From the perspective of cadets, this involvement is dictated by a high level of interest in the prison subculture and the presence of distorted ideas about this phenomenon. On the part of correctional staff, we see the reasons why they become involved. We see the perception of the prison subculture as an opportunity to express oneself emotionally (using prison slang) or to relieve the stress of adapting to service in a correctional institution (using elements of the subculture so as not to stand out, but to look more experienced and authoritative).

Twenty percent have a borderline level of involvement, close to critical (that is, they share the values of the subculture, justify its existence, consider it a possible tool in their professional activity, but do not yet apply it in practice and do not live according to the norms of the prison subculture). This category, according to our observations, includes staff only. This level of involvement is explained by their narrowmindedness, small circle of interests, limited circle of communication, and a lack of interest in development.

Socio-psychological aspects that require adjustment

Based on the results obtained, we identified the main problems that require attention:

1. Many manifestations of the prison subculture are presented in the modern youth environment as the norm of communication, and young correctional staff do not see anything reprehensible in demonstrating anti-legal behavior, disrespect for the state and the law, and disregard for people, which is all typical of the prison subculture. Therefore, cadets and young staff become infected with the subculture spontaneously, while simply being in the general information flow of modern youth culture, and often cannot identify the manifestations of the prison subculture in their communication and behavior.

2. Staff consider the prison subculture an important part of the overall mechanism of social interaction within the correctional institution and begin to unconsciously associate themselves with it if they do not have formed ideas about themselves as a servant of the law and a carrier of humanistic values, consider the prison subculture a convenient "working tool" and do not know how to arrange work with the help of other methods.

The first problem is related to the lack of objective and complete information about the prison subculture, and the second is related to the weakness of the individual, low level of awareness and insufficient formation of ideas about the possibilities of resisting the influence of the prison subculture.

Prevention of the spread of the prison subculture requires the implementation of a system approach. Its negative impact should be mitigated in the following three directions - general social, special and individual [5; 7; 9].

\section{Program for preventive measures}

Based on these problems, a program for correctional and preventive work was drawn up.

The goal of the program is to neutralize the negative impact of the prison subculture on the officer's personality at the cognitive and motivational level.

To achieve this goal, it was necessary to address the following tasks:

- inform about the history, development and essence of the prison subculture;

- carry out work on the formation of ideas about oneself as a Russian officer, representing high culture and the law, a defender of humanistic values;

- to form a negative attitude toward the prison subculture, which will encourage one to distance oneself from its norms and manifestations;

- training to resist the influence of the prison subculture and to eliminate elements of the prison subculture in official activities and communication.

All those who were involved in the previous stage were included in the implementation of the program, but the main target audience was those cadets and staff who were at risk (that is, had a borderline degree of involvement in the prison subculture).

To participate in the program, cadets and staff were divided into groups of 20 people. Each lesson lasted 1.5 hours. 
The first stage of the program was informing. This stage included two lessons. The first lesson dealt with the history of the formation of the prison subculture, the formation of its ideology and philosophy, and its functions in the world of crime. The second lesson dealt with the negative impact of the prison subculture on the personality and life of inmates and staff. The lesson was conducted in the form of a problem lecture with visualization elements.

Within the framework of this direction, the following topics were proposed for discussion:

- Manifestations of the negative influence of criminal subculture in a modern correctional institution.

- History of the development of criminal subculture.

- Functions, expediency, and classification of prison subculture attributes.

- Negative impact of the prison subculture on the personality and behavior of correctional staff.

- Offenses dictated by the influence of criminal subculture.

Theoretical information was provided in short blocks (10 minutes), followed by a stage of discussion of problematic issues, such as:

- How do the conditions of a correctional institution contribute to the spread of criminal subculture?

- What is the attraction of criminal subculture for a correctional officer?

- What measures to combat the spread of criminal subculture could be effective?

- etc.

To illustrate the material, participants were shown some videos of the real manifestations of the prison subculture, its negative impact on the socio-psychological climate in the institution, the personality and life of inmates and staff.

For example, a great response from the audience was caused by the film Kalina Krasnaya [The Red Snowball Tree] (1974), which, despite its age, does not lose its relevance and shows the long-term implications of joining the "thieves' life": loss of family, mother's grief, difficulties with restoring social ties, disrespect of people and, as a result, the inability to simply get out of this vicious circle.

The second stage of the program was aimed at actively teaching socially important behavioral skills that help to resist the influence of the prison subculture and eliminate elements of the prison subculture in official activities and personal communication.
For the successful implementation of this stage, it was important to unlock personality resources of the staff, to form professional selfesteem and professional pride in them, and to minimize negative consequences of the influence of the prison subculture. The work was aimed at forming the staff's image of themselves as an officer, a defender of law-abiding citizens, a servant of the law; developing the skills of responsible behavior and the ability to predict the consequences of their actions; developing the ability to resist the negative influence of the environment and the group.

In the framework of our research, this task was solved during training sessions. Three classes were conducted (work in groups of 20 people for 1.5 hours).

The first lesson was aimed at understanding the reasons for showing interest and involvement in the prison subculture (both at the level of society and at one's personality level). We used brainstorming methods, working in subgroups and pairs.

The second lesson was aimed at training the skill of determining the manifestations of the prison subculture in the activities of correctional staff. The participants of the group were offered various situations from the activities of the institution, in which it was necessary to identify elements of the manifestation of subculture and evaluate the actions of staff, to offer an alternative to such actions. Elements of the case method and role-playing games were used.

The third lesson was aimed at the formation and consolidation of socially important forms of behavior that would help to oppose the prison subculture. In this lesson, the short- and longterm benefits of abandoning the prison subculture were worked out, the motivation for following the chosen direction of behavior was formed, and the resources that could be supported in this process were determined.

At the final stage of the program, a final group meeting was held, where the results were summed up, discussed, feedback was collected, and a control questionnaire survey was conducted.

In the course of the program implementation, the following results were obtained:

The number of participants in the program demonstrating a critical level of involvement in the prison subculture decreased from $75 \%$ to $30 \%$. The decrease occurred both at the expense of those respondents who were closer to superficial involvement at the beginning of the 
program, and those who were closer to critical involvement.

The program participants noted the following changes:

- they obtained more comprehensive knowledge about the prison subculture, allowing them to draw their own conclusions about its essence, functions in the modern world and the need to preserve it;

- they began to think about the long-term consequences of involvement in the prison subculture and see its destructive impact;

- they began to notice the manifestations of the prison subculture in their behavior and the behavior of other people, in mass culture and in the general information space;

- there was an understanding of the seriousness and scale of the problem and the confidence that its spread can be controlled by personal efforts: not to allow it at home, to give a correct assessment in society, to speak about its real content, etc.;

- there emerged a desire not to associate themselves with the world of crime through the separation of slang words, rituals and norms of behavior;

- they developed an understanding that difficult situations in a correctional institution should be solved by legal methods; they wanted to learn more about it, to become a real professional in their field;

- they developed a sense of pride in their profession.

At this level, we can say that the hypothesis of our study was confirmed and the goal of the study was achieved. But in order to make global changes and ensure that the changes are consolidated, it is necessary for the administration of the correctional institution and educational organizations to carry out measures of a general systemic nature.

First, it is necessary to conduct constant monitoring of open information sources. Since young people are active users of social media, it is important to respond in a timely manner to the resonant material that appears in popular blogs and video channels. Open discussion and professional evaluation of provocative materials will allow cadets and young staff to navigate the situation correctly and draw the right conclusions.

Second, it is necessary to conduct constant work to identify and suppress the manifestations of elements of the prison subculture in staff's behavior. It is important to constantly demonstrate a position of intransigence to such trends, openly condemning the revealed facts of the manifestation of the prison subculture among staff and encouraging those who systematically adhere to the norms of legal and humanistic behavior.

And third, attention should be paid to improving the general cultural level of officers, forming healthy lifestyle habits, engaging in volunteering and charity, and engaging in public activities (including measures to prevent the spread of the prison subculture among minors).

\section{REFERENCES}

1. Anfinogenov V.A. Human needs, interests and values in the prison subculture. Obshchestvo $i$ pravo=Society and Law, 2014, no. 1 (47). Available at: https://cyberleninka.ru/article/n/chelovecheskie-potrebnosti-interesy-i-tsennosti-vtyuremnoy-subkulture (accessed May 19, 2021). (In Russ.).

2. Belousova M.M., Koval'chuk O.V., Rimskii V.P. Methodology of subcultures studies in social sciences and humanities. Paper 2. Genesis and evolution of subcultures of childhood and youth. Nauchnye vedomosti BelGU. Seriya "Filosofiya. Sotsiologiya. Pravo"=Belgorod State University Scientific Bulletin. Philosophy. Sociology. Law, 2010, no. 8 (79), issue 12, pp. 30-40. (In Russ.).

3. Gusev M.V. The problem of the spread of the criminal subculture in Russia. Vestnik Kuzbasskogo gosudarstvennogo tekhnicheskogo universiteta=Bulletin KuzSTU, 2007, no. 5, pp. 112-115. (In Russ.).

4. Kleimenova E.G. Prison subculture as a special type of social interaction. Vestnik Udmurtskogo universiteta. Seriya "Filosofiya. Psikhologiya. Pedagogika"=Bulletin of Udmurt University. Series Philosophy. Psychology. Pedagogy, 2012 , no. 4. Available at: https://cyberleninka.ru/article/n/tyuremnaya-subkultura-kak-osobyy-vid-sotsialnogo-vzaimodeystviya (accessed October 12, 2020). (In Russ.).

5. Knyazeva O.V. Sivtsova M.O. Neutralizing the influence of the prison subculture as a component of the process of preventing prison-related crime In: Teoreticheskie i prakticheskie problemy razvitiya ugolovno-ispolnitel'noi sistemy v Rossiiskoi Federatsii i za rubezhom. Sbornik tezisov vystuplenii i dokladov uchastnikov Mezhdunarodnoi nauchnoprakticheskoi konferentsii [Theoretical and practical problems of the development of the penal system in the Russian Federation and abroad. Collection of abstracts of speeches and reports of participants of the international research-topractice conference]. 2018. Pp. 607-613. (In Russ.).

6. Kozhevnikov T.S. Tyuremnaya subkul'tura: ucheb. posobie [Prison subculture: a textbook]. Second edition, revised and supplemented. Kirov: FKOU DPO Kir. IPKR FSIN Rossii, 2013. P. 31.

7. Luzgin S.A. Directions, strategies and programs for the prevention of elements of prison subculture among young people. In: Filippov M.N. (Ed.). Materialy devyatnadtsatoi Vserossiiskoi nauchno-prakticheskoi konferentsii posvyashchennoi pamyati doktora pedagogicheskikh nauk, professora, Zasluzhennogo deyatelya nauki RF Ivana Pavlovicha Bashkatova 
[Proceedings of the nineteenth All-Russian scientific and practical conference dedicated to the memory of Ivan Pavlovich Bashkatov, Doctor of Sciences (Pedagogy), Professor, Honored Scientist of the Russian Federation]. 2019. Pp. 128-133. (In Russ.).

8. Luzgin S.A., Kirillova T.V., Kuznetsov M.I. Prevention of the spread of the prison subculture among adolescents and youth. Vedomosti UIS=Bulletin of the Penal System, 2019, no. 7 (206). Available at: https://cyberleninka.ru/article/n/profilaktikarasprostraneniya-tyuremnoy-subkultury-v-srede-podrostkov-i-molodezhi (accessed March 1, 2021). (In Russ.).

9. Naruslanov E.F., Novikov A.V., Gorovoi V.V. Prevention of youth extremism in institutions of the penal system. Yuridicheskaya nauka=LegalScience, 2019, no. 3. Available at: https://cyberleninka.ru/article/n/profilaktika-molodezhnogo-ekstremizmav-uchrezhdeniyah-ugolovno-ispolnitelnoy-sistemy (accessed March 1, 2021). (In Russ.).

10. Oleinik, A.N. Tyuremnaya subkul'tura v Rossii: ot povsednevnoi zhizni do gosudarstvennoi vlasti [Prison subculture in Russia: from everyday life to state power]. Moscow, 2001. 418 p.

11. Polishchuk V.E., Ponomarev S.B. To the issue of the axiology of prison subculture. In: Penitentsiarnaya bezopasnost': natsional'nye traditsii i zarubezhnyi opyt. Materialy Vserossiiskoi nauchno-prakticheskoi konferentsii, v 2-ukh chastyakh [Penitentiary security: national traditions and foreign experience. Materials of the All-Russian scientific and practical conference, in 2 parts]. Samarskii yuridicheskii institut FSIN Rossii. 2019. Pp. 180-182. (In Russ.).

12. Ponomarev S.B. Prison subculture from the standpoint of the theory of systems. Vedomosti UIS=Bulletin of the Penal System, 2020, no. 1 (212). Available at: https://cyberleninka.ru/article/n/tyuremnaya-subkultura-s-pozitsii-teorii-sistem (accessed May 19, 2021). (In Russ.).

13. Rumyantsev N.V. On the status and measures for the prevention of criminal subcultureamong minors held in the institutions of the penitentiary system. Vestnik Moskovskogo universiteta MVD Rossii=Bulletin of Moscow University of the Ministry of Internal Affairs of the Russian Federation, 2019, no. 3. Available at: https://cyberleninka.ru/article/n/o-sostoyanii-imerah-po-profilaktike-kriminalnoi-subkultury-sredi-nesovershennoletnih-soderzhaschihsya-v-uchrezhdeniyah-ugolovno (accessed March 1, 2021). (In Russ.).

14. Tishchenko N.V. Tyuremnaya subkul'tura v prostranstve kul'turnykh praktik. Avtoref. diss. na soisk. uch. st. doktora kul'tur [Prison subculture in the space of cultural practices. Doctor of Culture dissertation abstract]. Saratov, 2013. $42 \mathrm{p}$.

15. Tkacheva E.P. Game function in prison subculture. Vestnik VyatGU=Herald of Vyatka State University, 2008, no. 4. Available at: https://cyberleninka.ru/article/n/funktsii-igry-v-tyuremnoy-subkulture (accessed May 19, 2021). (In Russ.). 16. Yunusov A.A., Yunusov S.A., Zhezlov N.V. Prevention of the spread of subculture among those sentenced to imprisonment through the organization of religious education. Ugolovnoe sudoproizvodstvo: problemy teorii $i$ praktiki=Criminal Proceedings: Problems of Theory and Practice, 2017, no. 4, pp. 51-53. (In Russ.).

17. Percival G.L. Smart on Crime: The Struggle to Build a Better American Penal System. CRC Press, 2015. 265 p.

18. Cavadino M., Dignan J., Mair G., Bennett J. The Penal System: An Introduction. SAGE Publications, 2019. 413 p.

19. Weston J. Medicine, the Penal System and Sexual Crimes in England, 1919-1960s: Diagnosi ng Deviance. London: Bloomsbury Publishing, 2017. 263 p.

\section{INFORMATION ABOUT THE AUTHORS}

VITALII E. LAPSHIN - Doctor of Sciences (Pedagogy), Candidate of Sciences (Law), Associate Professor, professor of the Department of Personality Psychology and Special Education at Vladimir State University Named After Alexander and Nikolay Stoletovs, Vladimir, Russian Federation, professor of the Department of Psychology and Pedagogy of Professional Activity at Vladimir Law Institute of FSIN Russia, Vladimir, Russian Federation, professor of the Department of Legal Psychology and Pedagogy at Vologda Institute of Law and Economics of FSIN Russia, Vologda, Russian Federation. ORCID: https://orcid. org/0000-0002-6243-9532, e-mail: ve_lapshin@mail.ru

TAT'YANA V. GALICH - Candidate of Sciences (Psychology), associate professor of the Department of Psychology and Pedagogy of Professional Activity at Vladimir Law Institute of FSIN Russia, Vladimir, Russian Federation. ORCID: https:// orcid.org/0000-0001-5111-4698, e-mail: t_galich@list.ru 